\title{
The Effect of Motivation on Employee Performance Through Employee Satisfaction of The Tax Office in Surakarta
}

\author{
Dodik Jatmika ${ }^{1}$, Mardiana Andarwati ${ }^{2}$ \\ ${ }^{1}$ Kahuripan Kediri University, East Java, Indonesia \\ dodik_jatmika@kahuripan.ac.id \\ ${ }^{2}$ Merdeka Malang University, East Java, Indonesia \\ mardiana.andarwati@unmer.ac.id
}

\begin{abstract}
The purpose of this study is to find the effeect of motivation on employee performance through employee satisfaction of the tax office in Surakarta. The population of this study totaled 107 employees and all serve as a sample research. The result of research shows that (1) the motivation influential on satisfaction of employees, (2) the motivation does not influence on the performance of employees, (3) satisfaction work influential on the performance of employees, and (4) the motivation influential on the performance of employees through satisfaction work employees in Pratama Surakarta tax service office.
\end{abstract}

Keywords: Motivation, satisfaction and performance

\section{Introduction}

The performance of employees is really needed in the service office as a unit directly related to the community. According to Stoner, (1996: 118) performance is an achievement that can be shown by employees or achievements that can be achieved by a person or organization based on certain criteria and measuring instruments. The high performance is expected from all employees in Pratama Surakarta tax service office., not only at the leader of office, but also on all employees. Research conducted by Tampi (2014) explains that the motivation given by leader to employees can improve employee performance.

Job satisfaction is the attitude and general feeling of a worker to his work (Robbins, 2002: 184). Factor of employee job satisfaction according to (Munandar, 2012: 357), among others; 1. Intrinsic characteristics of work, 2. Income salary, fair rewards (Equittable Reward), 3.
Supervision, 4. Supporting colleagues, 5. Working conditions which support.

Employee satisfaction or employe unsatisfaction may affect employee performance, so that employees can feel satisfied in carrying out their work required motivation in carrying out their work. According to Maslow (1970: 223) Motivation is the desire or needs background someone to work.

\section{Literature}

\subsection{Performance}

Performance has become daily language in an organization. Definition of performance is the achievement of a person or organization in achieving the goals as the opinion of Stoner (1996: 118) while According to Jatmika and Andarwati performance (2017) is a record of the results generated on a particular job. 


\subsection{Job satisfaction}

Employee job satisfaction is the result of labor-related work motivation (Munandar, 2012, 350). factors of employee job satisfaction according to (Munandar, 2012, 357), among others; 1 . Intrinsic characteristics of the job, 2. Salary income, fair rewards (Equittable Reward), 3. Supervision, 4. Colleagues who support, 5. Working conditions which support. Job satisfaction is fulfilled some desire and needs through work or work activities

\subsection{Motivation}

Motivation is the desire or needs that motivates a person to work (Maslow, 1970: 223), needs theory from Maslow. Needs can be defined as a gap or contradiction experienced between reality and the inner impulse. According to Abraham Maslow, human needs are: (a) Physiological needs are necessary to maintain one's survival, such as eating, drinking, air, and house. In organizations, these needs can be like money, entertainment, pension programs, comfortable working environment. (b) safety and security needs are the security needs of the threat of feeling safe from the threat of accidents in doing the job. In organizations this requirement can be like safety of job security, seniority, job termination program, severance pay. (c) social need is the need for friends, love and having. Social need in the organization can be team work both formally and informally. (d) the need for esteem need or status needs is the need for self-esteem, recognition and prestige awards from employees and the society environment. (e) The need for self-actualization is the need for self-actualization by utilizing the skills, abilities, skills and optimal potential to achieve outstanding or extraordinary work performance that can not be reach by others people.

\section{Method \\ 3.1 Research design}

This research design using surve, that is research which use questioner as data collecting tool. Primary data of this study comes from KPP Pratama Surakarta because the target of tax revenue and achievement of KPP Pratama Surakarta is the biggest among the KPP in Kanwil Jawa Tengah II.

\subsection{Operational definition}

Perfomance

Performance is the success of achieving the target of an employee's work. Performance is measured through three indicators, namely: quantity, quality, and time

Job satisfaction

Job satisfaction is a person's feelings for what is done in his job. Measured using five indicators, namely: Income salary, perceived benefits fair, colleagues who support, working conditions which support.

Motivation

Motivation is an encouragement or a seminal of both the external and the external to achieve the goal. Measured by four indicators namely: Physiological needs, Needs sense of security, Social needs, Needs appreciation

\subsection{Population and sample}

Population in this research is all staff of KPP Surakarta which amounted to 111 employees and all made in sample. 
International Journal of Economics, Business and Accounting Research (IJEBAR)

Peer Reviewed - International Journal

Vol-2, Issue-1, 2018 (IJEBAR)

ISSN: 2614-1280, https://jurnal.stie-aas.ac.id/index.php/IJEBAR

4. Research results

The result of testing model of stuctural
Equation SEM test results are tested there is no problem multicellularity outlier and normal distributed data.

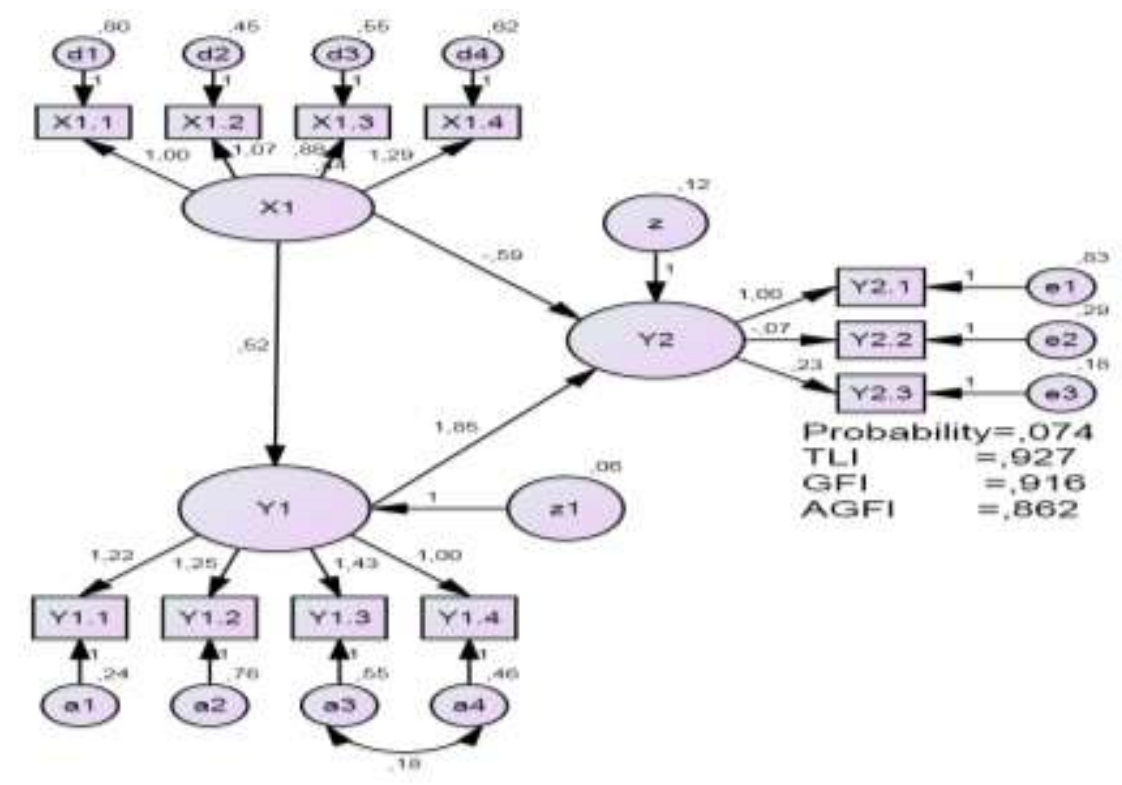

Picture 1. Result of Structural Research Model

\section{Y2. Employee Performance}

Y2.1 quantity

Y2.2 quality

Y2.3 time

\section{Y1. Job satisfaction}

Y1.1 Income salary

Y1.2 benefits felt fair

Y1.3 colleagues who support

Y1.4 supporting working conditions

\section{Motivation}

X1.1 Physiological Needs

X1.2 safety and security need

X1.3 Social need

X1.4 asteemneed or status needs

The result of SEM analysis is done with computer program AMOS 16 for windows. It is known that all items goodness of -fit the indeset qualify as shown in table 1 . 
International Journal of Economics, Business and Accounting Research (IJEBAR)

Peer Reviewed - International Journal

Vol-2, Issue-1, 2018 (IJEBAR)

ISSN: 2614-1280, https://jurnal.stie-aas.ac.id/index.php/IJEBAR

Table 1

Goodness of-fit indeces point and cut off model SEM

\begin{tabular}{|l|l|l|l|}
\hline Criteria & Cut-of Value & Result of the test model & Explanation \\
\hline Signifikansi probabilitas & $\geq 0.05$ & 0.074 & Baik \\
\hline CMIN/DF & $\leq 2.00$ & 1.139 & Baik \\
\hline RMSEA & $\leq 0.08$ & 0.057 & Baik \\
\hline GFI & $\geq 0.90$ & .916 & Baik \\
\hline TLI & $\geq 0.90$ & .927 & Baik \\
\hline
\end{tabular}

Source: primary data processed 2018

Table 1. Demonstrate the results of structural equation model testing. The

results are tested that the probability value and TLI have met the recommended.

Table 2. Hypothesis Testing

\begin{tabular}{|l|l|l|c|c|c|}
\hline \multicolumn{2}{|c|}{ Variable } & Direct & Indierct & Prob \\
\hline Motivation & $\rightarrow$ & Job statisfaction & 0.819 & & 0.000 \\
\hline Motivation & $\longrightarrow$ & Performance & -.638 & & 2.54 \\
\hline Job statisfaction & $\rightarrow$ & Performance & 1.264 & & 0.045 \\
\hline Motivation & $\longrightarrow$ & Performance through job statisfaction & & 1.04 & 0.000 \\
\hline
\end{tabular}

\section{Discussion}

5.1 Influence of motivation on employee job satisfaction of Surakarta pratama tax office.

Based on the results of research proved that motivation has a significant effect on employee job satisfaction of Surakarta pratama tax office . Motivations reflected in achievement awards and status awards are given so that employees work in accordance with their abilities and employees work with a sense of responsibility.

5.2 The influence of motivation on the employee performance of Surakarta pratama tax office. Based on the results of research proved that the motivation does not affect to the employee job satisfaction of Surakarta pratama tax office. Motivations reflected in achievement awards and status awards are given but no permanent employees do not complete the workload set by the company and
Employees are not willing to complete work outside working hours.

5.3 The influence of job satisfaction on the employee performance of Surakarta pratama tax office. Based on the results of research proved that job satisfaction affect to the employees performance of Surakarta pratama tax office. Job satisfaction is reflected in the Employees work in accordance with their capabilities and Employees work with a sense of responsibility to encourage Employees to complete the workload that has been established company and Employees willing to complete work outside working hours.

5.4 The influence of motivation on employee performance through employee job satisfaction of Surakarta pratama tax office. Based on the results of research proved that the motivation effect on employee performance through employees job satisfaction of Surakarta Pratama tax office. Motivation reflected in achievement awards and status awards 
are given so that Employees work in accordance with their capabilities and Employees work with a sense of responsibility and can encourage Employees to complete the workload that has been established company and Employees willing to complete work outside working hours

\section{Conclusion and Suggestion}

\subsection{Conclusion}

6.1.1 Motivation has a significant effect on employees job satisfaction of Surakarta pratama tax office.

6.1.2 Motivation does not affect the employees job satisfaction of Surakarta pratama tax office.

6.1.3 Job satisfaction affects the employees performance of Surakarta pratama tax office.

6.1.4 Motivation affects the employees performance through employees job satisfaction of Surakarta pratama tax office.

\subsection{Suggestion}

\subsubsection{Academics}

The results of this study are expected to enrich and develop the conception of job satisfaction and employee performance in science studies.

\subsubsection{Practitioner}

The results showed that the motivation can not improve directly the performance of employees, in order to improve employee performance must be mediated by job satisfaction, because if employees are satisfied with the results of work that has been done employees will work better.

6.2.3 Further research

It is suggested to the next researcher to investigate using indicators of performance as a variable to measure performance.

\section{Acknowledgements}

Upon completion of this research I say many thanks to the University of Kahuripan Kediri and Merdeka University of Malang who have provided support.

\section{References}

Jatmika, Dodik dan Andarwati, Mardiana. 2017. Pengaruh Pengembangan Sumberdaya Manusia Terhadap Kinerja Pegawai Melalui Kepuasan Kerja Pegawai Kementrian Agama di Jombang. Seminar Nasional Sistem Informasi (SENASIF), 14 September 2017 h. 395-407

Maslow, H Abraham. 1970. Motivation and Personality. New York: Harper \& Row Publisher

Munandar, S.C. Utami. 2012. Pengembangan Kreativitas Anak Berbakat. Penerbit Rineka Cipta. Jakarta.

Stoner James. 1996. Manajemen, Edisi Bahasa Indonesia. Penerbit PT. Prenhallindo, Jakarta

Robbins Stephen P. 2002. Prinsip-prinsip Perilaku Organisasi. Penerbit Erlangga, Jakarta (Edisi Kelima)

Tampi. 2014. Pengaruh Gaya Kepemimpinan Dan Motivasi Terhadap Kinerja Karyawan pada PT. Bank Negara Indonesia, TB. Jurnal Acta Diurna Vol. 3. 